УДК 338.48(477)

\title{
ПОНЯТТЯ REVENUE МЕНЕДЖМЕНТУ В ГОТЕЛЬНОМУ БІЗНЕСІ
}

\section{THE CONCEPT OF REVENUE MANAGEMENT IN THE HOTEL BUSINESS}

\author{
Шикіна Ольга Володимирівна \\ кандидат економічних наук, доцент, \\ Одеський національний економічний університет \\ ORCID: https://orcid.org/0000-0001-5294-3367 \\ Ремігайло Ілона Юріївна \\ викладач, \\ Одеський національний економічний університет \\ ORCID: https://orcid.org/0000-0002-7674-9953
}

\author{
Shykina Olga, Remigailo Ilona \\ Odesa National Economic University
}

\begin{abstract}
Стаття присвячена актуальному питанню визначення поняття revenue менеджмент, його місцю у готельному бізнесі, перспективі застосування та імовірному ефекту від гнучкого ціноутворення у період кризи пандемії. Проаналізовано походження терміну, визначено з якої галузі даний термін прийшов до готельного бізнесу. Наведено які міжнародні готельні мережі першими спробували застосовувати revenue менеджмент. Визначено вимоги, що висуваються до revenue менеджерів, які обов'язки вони повинні вміти виконувати. Наведено рівні системи revenue менеджменту. Визначено напрями діяльності готелю, що фрормують суть revenue менеджменту (управління доходами). Визначено, що більшість готелів, що відносяться до міжнародних мереж активно використовують інструменти revenue менеджменту. В Україні ця практика почала розвиватися останні 10 років під тиском міжнародних мереж, які почали появлятися у 2005 році.
\end{abstract}

Ключові слова: revenue менеджмент, готельний бізнес, ціноутворення, yield management.

Статья посвящена актуальному вопросу определения понятия revenue менеджмент, его месту в гостиничном бизнесе, перспективе применения и вероятному эффекту от гибкого ценообразования в период кризиса пандемии. Проанализировано происхождение термина, определено из какой отрасли данный термин пришел в гостиничный бизнес. Приведены международные гостиничные сети, которые первыми попытались применять revenue менеджмент. Определены требования, предъявляемые к revenue менеджерам, какие обязанности они должны уметь выполнять. Приведены уровни системы revenue менеджмента. Определены направления деятельности гостиницы, формирующие сущность revenue менеджмента (управление доходами). Определено, что большинство отелей, относящихся к международным сетям, активно используют инструменты revenue менеджмента. В Украине эта практика начала развиваться в последние 10 лет под давлением международных сетей, которые начали появляться в 2005 году.

Ключевые слова: revenue менеджмент, гостиничный бизнес, ценообразование, yield management.

The article is devoted to the topical issue of defining the concept of revenue management, its place in the hotel business, the prospects of application and the likely effect of flexible pricing during the pandemic crisis. The origin of the term is analyzed, it is determined from which branch the term came to the hotel business. The term "revenue management" was first used as a term in the works of leading airline professionals. British Airlines was the first to use "discount prices" for flights of its aircraft with the Early Bird tariff plan, ie early booking. American Airlines has gone even further by using price discrimination (selling the same product at different prices at different times) and forecasting consumer demand. It was American Airlines President Robert Crandall who introduced the term "yield management" as a way to maximize revenue and co-founded a loyalty program for frequent flyers. However, the term "yieldt" for hotels was not entirely appropriate, so it was replaced by "revenue". It is given which international hotel chains were the first to try to apply revenue management. Marriott was the first to adapt airline profitability management strategies to the hotel business and saw big profits. The next step was the differentiation and segmentation of guests in the hotel chain InterContinental Hotels Group. Defines the requirements for revenue managers and what 
responsibilities they should be able to perform. The levels of the revenue management system are given. The directions of hotel activity that form the essence of revenue management (revenue management) are determined. It is determined that most hotels belonging to international networks actively use revenue management tools. In Ukraine, this practice began to develop in the last 10 years and under the pressure of the same international networks that began to appear in our country only in 2005. However, even today this area of activity is still underestimated. In many hotels, revenue managers combine their activities with booking or sales, and are subordinate to their managers, who limit their capabilities.

Keywords: revenue management, hotel business, pricing, yield management.

Постановка проблеми. Revenue менеджмент - термін, який буквально означає «управління доходами». Багато спеціалістів, говорячи про revenue менеджмент, розуміють вузьконаправлену практику управління відкритою ціною готелю на основі прогнозування попиту, тобто технологію формування цінової політики на основі ринкових змін 3 метою збільшення дохідності готельного підприємства. Проте, реально цей напрям діяльності в готельному бізнесі $€$ значно ширшим і передбачає не тільки основи та принципи ціноутворення, управління відкритими каналами продажу, але й науковий підхід до сегментації гостей, вміння прогнозувати попит, навички управління номерним фондом, контроль за завантаженістю, оптимізацію витрат готелю і, звичайно, оцінку діяльності готелю, як підприємства.

Аналіз останніх досліджень і публікацій. Дослідженню revenue менеджменту в сорері готельного управління у професійній літературі приділено небагато уваги. Основними джерелами $€$ іноземні статті та видання 3 економіки та логістики. Основні положення відображені у працях Dar M. \& Wilson N. [1], Sharma P. [2], Josephy S., Aubke F. \& Stierland M. [3].

У своїй роботі Dar M. \& Wilson N. [1, с. 15] зазначає, про існування у сорері авіа-бізнесу так званих менеджерів 3 доходів, які мають оцінювати, скільки бронювань можна очікувати по кожному тарифу та класу, а потім вирішати, які саме бронювання приймати.

На думку P. Sharma [2], revenue менеджмент полягає у співвідношенні пропозиції та попиту, основаному на диверсифрікації потреб споживача. Вдалий менеджмент, сегментуючи ринок, прагне до задоволення навіть майбутніх потреб споживача та має за мету підвищення кінцевого прибутку підприємства.

Так, у статті S. Josephi, F. Aubke \& M. Stierland [3, с. 2] звертає увагу на те, що донедавна у сорері готельної індустрії управління доходами зосереджувалося переважно на оптимізації потенціалу доходу від існуючого попиту. Ґрунтуючись на технологічними досягненнями, система управління доходами при прийнятті рішень почала включати внески з інших джерел доходів від діяльності готелю. Інтернет дозволив готельним операторам повідомляти про ціни та наявність місць своєї продукції швидким та ефективним шляхом до ринку через їх власний прямий канал, або за допомогою необмеженої кількості партнерів 3 дистрибуції. Водночас зросла прозорість тарифрів, що дозволила споживачам легко отримувати та порівнювати інформацію, змушуючи готелі більше підходити до ціноутворення науковим способом. У поєднанні з наявністю нових джерел даних, які допомагають приймати рішення щодо управління доходами, включаючи онлайн-огляди гостей та пов'язані рейтинги, управління доходами просунулося 3 управління потужністю до оптимізації цін [3, с. 2].

Серед вітчизняних науковців можна виділити роботи Мазаракі А., Бойко М., Кулик М. [4], Костин К.Б. [5], Ремігайло І.Ю. [6].

Формулювання цілей статті. Метою статті $€$ виявлення місця revenue менеджменту у процесі управління готелем.

Виклад основного матеріалу дослідження. На нашу думку «revenue менеджмент» $€$ невід'ємною частиною злагодженої роботи будь-якого закладу тимчасового розміщення туристів. Термін «revenue менеджмент» був вперше застосовано як термін у працях провідних срахівців авіакомпаній.

Першою, хто використав прийом «знижкових цін» на рейси своїх літаків, стала British Airlines 3 тарифрним планом Early Bird, тобто раннє бронювання. Компанія American Airlines пішла ще дальше використавши методи цінової дискримінації (продаж одного й того ж продукту за різною ціною в різний час) та прогнозування споживчого попиту. Саме президент American Airlines Роберт Крендал ввів такий термін як «yield management» - стратегія змінної ціни як способу максимізації доходів і став засновником програми лояльності для пасажирів, які часто літають. Проте термін «yieldt» для готелів був не зовсім доречним, тому його замінили на «revenue». 
Управління доходами - це підхід, орієнтований на залишки, який відповідає правильному продукту перед ідеальним клієнтом за найкращою ціною. І авіакомпанії, і готелі мають так званий швидкопсувний продукт або залишки, які не можна продати, коли рейс вилетів або минула ніч. Лише в кінці 1980-х років готелі почали експериментувати з управлінням доходами.

B. Marriott був першим, хто адаптував стратегії управління прибутковістю авіаліній до готельного бізнесу та побачив великі прибутки, як колись сказав Білл Марріотт - молодший, голова та виконавчий директор Marriott International: «Управління доходами зробило мільйони результатів, і це навчило наших людей більш ефективно керувати своїм бізнесом. Коли ви зосереджуєтесь на кінцевому підсумку, ваша компанія зростає» [7].

Як тільки інші бренди готелів побачили yспіx Marriott, управління доходами готелів стало звичайною практикою у всій галузі. Готелі стали навмисно оптимізовувати доходи від номерів (ціноутворення) та заповнюваність (обсяг бронювання) за допомогою змінних стратегій ціноутворення на основі таких фракторів, як попит, вікна бронювання та ринкові умови.

Наступним кроком стало диференціація та сегментація гостей у готельній мережі InterContinental Hotels Group.

Але впровадження revenue менеджменту в готельній індустрії мало свої особливості [8, с. 159]. По-перше, у готелях не було налагодженої системи збору інформації про гостей щодо аналізу темпів бронювання. По-друге, якщо авіакомпанія отримує дохід за місце протягом доби, то в готелях номер може бути замовленим на декілька ночей.

Тобто, revenue менеджмент - аналітичний процес, який за допомогою маркетингових інструментів, виявляє потреби споживачів до покупки, аналізуючи попередні показники продажу, дає підприємству чітку стратегію цінової політики на певний період часу. Термін «управління доходами» відноситься до бізнес-практики, що покликана оптимізувати потенціал доходу активів за всіх ринкових умовах.

Досить часто такий вид діяльності доручається менеджеру з продажів та зводиться до простого правила «продавати вчасно за актуальною ціною потрібному споживачеві». Однак, для повноцінного втілення revenue менеджменту потрібно значно розширити звичний термін «продаж» та приді- лити більше уваги дослідженню попиту та динаміці основних та додаткових показників роботи готелю. Управління прибутковістю $€$ основним компонентом управління доходами будь-якого підприємства. Для застосування його потрібні наступні умови:

- фріксований «ліміт» ресурсу, що продається. Не проданий номер сьогодні не буде проданим ніколи. Це товар, що «псується» швидше за інші;

- за однакову послугу / товар різні споживачі можуть платити різну ціну;

- $є$ можливість передбачити певний попит на послуги.

Так, revenue менеджмент протягом останніх 30-ти років трансформувався із звичайного обліку доходів підприємства на систему збору аналітичних даних та обробку останніх для прийняття найвигіднішої стратегії продажу готельних номерів. Для втілення повноцінного revenue менеджменту бажаним $€$ наявність на підприємстві менеджеру 3 доходів (revenue manager). Для обіймання вищезазначеної посади кандидат повинен:

- мати вищу професійну освіту у сорері організації готельного господарства;

- мати досвід роботи в готелях від 5 років.

Наразі, така посада присутня у більшості своїй у мережевих готелях, фрахівці з прогнозування попиту мають багатий досвід роботи у готелях та отримали відповідну додаткову освіту, працюючи у іноземних мережевих готелях $[9 ; 10]$. До щоденних обов'язків revenue менеджера відносяться наступні:

- створення тарифної сітки готелю на основі даних фрінансового департаменту про мінімальну собівартість послуг та бажаного відсотку надбавки;

- щоденний аналіз даних про попит на ринку;

- моніторинг цін на схожі послуги конкурентів;

- послідовне регулювання завантаженості готелю по сегментах споживачів;

- динамічне ціноутворення;

- складання щомісячного звіту роботи.

К.Б. Костін [5] розподіляє обов'язки revenue менеджера на рівні системи revenue менеджменту:

- Перший рівень передбачає створення глибоко продуманої системи збирання необхідних даних. Для готельного комплексу доцільно збирати максимум даних, пов'язаних із постояльцями: тривалість перебування, послуги, якими вони користувалися, повна інсрормація щодо їх витрат, 
сорера діяльності, доходи, сімейний стан, контактна інформація тощо. Чим повнішою буде інсормація на вході системи, тим точніше можна буде її оцінити і отримати найбільш точний результат на виході.

- Другий і третій рівні - це, власне, програмно реалізований математичний алгоритм, головне завдання якого $€$ створення оптимальної моделі попиту на той чи інший товар чи послуги. Функціонування механізму оптимізації може бути забезпечене введенням набору деяких вагових коефіцієнтів, які будуть вносити певні обмеження, завдяки чому, наприклад, можна ефективно вводити системи знижок.

- Четвертий рівень - контроль вихідних даних - відповідає за розподіл товарів чи послуг між відповідними маркетинговими сегментами - споживачами [5, с. 152].

Основна увага в науковій літературі 3 управління доходами (Josephy S., Aubke F. \& Stierland M.) зосереджена переважно на окремих етапах процесу управління доходами, a саме: покращені методів прогнозування, управлінню потужністю, ціноутворенню та розподілу сегментів споживачів. Більш пізні доповнення до літератури приділяють більше уваги оптимізації цін і включають різні доходи в процесі прийняття рішень, наприклад, фрункціональний простір та дохід від їжі, а також припускають, що менеджери 3 доходів повинні досліджувати всі потоки доходу від бізнесу, коли встановлюють ціни на номери або узгодження контрактів. Основну увагу менеджера має бути зосереджено на прибутковості в першу чергу. Зрештою, завданням менеджера 3 доходів $€$ управління загальним продуктом, включаючи відповідальність за маркетинг і загальну продуктивність [3].

Суть управління доходами (revenue менеджмент) в готелі можна узагальнено звести до таких напрямів діяльності:

- оцінка діяльності готелю, аналіз ключових показників його ефективності (KPI), визначення стратегії розвитку;

- вивчення ринку і свого конкурентного оточення;

- позиціонування готелю і визначення стратегії просування;

- аналіз попиту на основі історичних даних;

- визначення закономірностей та динаміки бронювання;

- сегментація основних гостьових груп;

- прогнозування попиту, оцінка ринку подієвих послуг;
- контроль доступності номерного фонду на відкритих каналах продажу, контроль за паритетністю ціни і представництво готелю в онлайн;

- використання прийомів фрільтрації заявок на бронювання, практика і прийоми перебронювання;

- використання прийомів, які стимулюють попит (upgrade, upsell, пакетні пропозиції);

- репутаційний контроль;

- впровадження практики, прийомів і технологій revenue менеджменту у всіх підрозділах готелю, які генерують дохід;

- оцінка діяльності готелю, аналіз КРІ та індексів змін, адаптація стратегії розвитку [6].

До початку XXI ст. практично всі міжнародні готельні мережі активно використовували інструменти revenue менеджменту тою чи іншою мірою. В Україні ця практика почала розвиватися останні 10 років і саме під тиском тих же ж міжнародних мереж, які почали появлятися у нас тільки в 2005 році. Проте і сьогодні цей напрям діяльності все ще недооцінений. В багатьох готелях revenue менеджери поєднують свою діяльність з роботою у відділі бронювання чи продажу, при цьому підпорядковуються своїм керівникам, які обмежують їх можливості [11].

Висновки. Застосування revenue менеджменту можливе лише за наявності певних умов, зокрема: гості готові платити різну ціну за одну і ту ж послугу або; бізнес має здатність заздалегідь передбачати зміну рівня попиту; для продажу в будь-який момент часу $є$ тільки фріксована кількість ресурсів; після певного моменту ресурси більше не можуть бути продані.

Отже, revenue менеджмент не тільки максимізує високий попит, але й допомагає стимулювати його в низькі періоди, уникаючи при цьому використання практики високих скидок. Таке управління доходами має довготерміновий стратегічний характер, враховує всі доходи з врахуванням їх прибутковості, визначає стратегію розвитку готелю. Сучасний інструментарій revenue менеджменту передбачає багато аналітичних елементів, які не обмежуються традиційними звітами готельної системи. 3 появою нових методів прогнозування і систем управління доходами (revenue management system) $€$ зміст переосмислити підхід до цього процесу, особливо в умовах нестабільного ринку. У сучасних реаліях важко уявити успішний готель без використання методик revenue менеджменту. 


\section{СПИСОК ВИКОРИСТАНИХ ДЖЕРЕЛ:}

1. Dar M. \& Wilson N. Modelling the Performance of Revenue Management Systems in Different Competitive Environments. Massachusetts Institute of Technology. 2006.

2. Sharma P. Hotel revenue management. URL: https://www.academia.edu/

3. Josephy S., Aubke F. \& Stierland M. Progress and Development of Hotel Revenue Management: A Comparative Content Analysis. URL: www.academiya.edu

4. Мазаракі А., Бойко М., Кулик М. Детермінанти ревеню-менеджменту в готельному бізнесі. Вісник Київського національного торговельно-економічного університету. 2017. № 4. С. 66-78. URL: http://visnik.knute.edu.ua/files/2017/04/6.pdf

5. Костин К.Б. Ревенью менеджмент как основа успешного развития индустрии туризма. Российское предпринимательство. 2012. № 11. С. 34-37.

6. Ремігайло І.Ю., Шикіна О.В. Revenue менеджмент, як інструмент удосконалення ціноутворення на підприємствах готельного господарства. Глокалізаційні аспекти інноваційного розвитку економіки : матеріали всеукраїнської науково-практичної конфреренції молодих вчених (м. Одеса, 21 жовтня 2021 року). Одеса : ОНЕУ, 2021. С. 66-69.

7. Mariott J.W. Without reservations. Biography. 2013.

8. Герасименко В.Г. Державне регулювання ссрери туризму України в контексті процесів євроінтеграції I За заг. ред. В.Г. Герасименко, О.Л. Михайлюк. Київ : ФОП Гуляєва В.М., 2019. 332 с.

9. Шикіна О.В., Нездоймінов С.Г. Моніторинг туристичного потоку в контексті стратегії регіонального розвитку. «Dezvoltarea sistemelor sociale și economice întrun mediu competitiv la nivel global», conferinta internationala știintificopractica (2016; Chisinau). Conferinta internationala știintifico-practica «Dezvoltarea sistemelor sociale și economice întrun mediu competitiv la nivel global». 29 februar. 2016. Chisinau, 2016. P. 167-171.

10. Шикіна О.В., Гончаренко Я.Є., Козловський Р.С. Тенденції розвитку європейського ринку готельних послуг. Науковий вісник Одеського національного економічного університету. Науки: економіка, політологія, історія. 2019. № 5(268). С. 216-233. URL: http://n-visnik.oneu.edu.ua/collections/2019/268/pdf/216-233.pdf

11. Шикіна О.В., Гончаренко Я.Є., Ремігайло І.Ю. Шляхи розвитку ділового туризму у період пандемії. Інфрраструктура ринку. 2020. № 50. С. 213-219. DOI: https://doi.org/10.32843/infrastruct50-35

\section{REFERENCES:}

1. Dar M. \& Wilson N. (2006) Modelling the Performance of Revenue Management Systems in Different Competitive Environments. Massachusetts Institute of Technology.

2. Sharma P. (2014) Hotel revenue management. Retrieved from :https://www.academia.edu/

3. Josephy S., Aubke F. \& Stierland M. (2014) Progress and Development of Hotel Revenue Management: A Comparative Content Analysis. Retrieved from: www.academiya.edu

4. Mazaraki A., Boyko M., Kulyk M. (2017) Determinanty reveniu-menedzhmentu v hotelnomu biznesi [Revenue management determinants in hospitality]. Visnyk Kyivskoho natsionalnoho torhovelno-ekonomichnoho universytetu, no. 4, pp. 66-78. Retrieved from: http://visnik.knute.edu.ua/files/2017/04/6.pdf

5. Kostyn K.B. (2012) Reveniu menedzhment kak osnova uspeshnoho razvytyia yndustryy turyzma [Revenge management as the basis for the successful development of the tourism industry]. Rossyiskoe predprynymatelstvo, no. 11, pp. 34-37. (in Russian)

6. Remihailo I.Yu., Shykina O.V. (2021) Revenue menedzhment, yak instrument udoskonalennia tsinoutvorennia na pidpryiemstvakh hotelnoho hospodarstva [Revenue management as a tool to improve pricing in the hotel industry]. Proceedings from: materialy vseukrainskoi naukovo-praktychnoi konferentsii molodykh vchenykh «Hlokalizatsiini aspekty innovatsiinoho rozvytku ekonomiky» - Proceedings of the All-Ukrainian Scientific and Practical Conference of Young Scientists «Globalization Aspects of Innovative Economic Development» (Odessa, October 21, 2021) (pp. 66-69). Odesa: ONEU. (in Ukrainian)

7. Mariott J.W. (2013) Without reservations. Biography.

8. Herasymenko V.H. (2019) Derzhavne rehuliuvannia sfery turyzmu Ukrainy v konteksti protsesiv yevrointehratsii [State regulation of tourism in Ukraine in the context of European integration processes] / V.H. Herasymenko, O.L. Mykhailiuk. (Eds.). Kyiv: FOP Huliaieva V.M. (in Ukrainian)

9. Shykina O.V., Nezdoiminov S.H. (2016) Monitorynh turystychnoho potoku v konteksti stratehii rehionalnoho rozvytku [Tourism flow monitoring in the context of regional development strategy]. Proceedings from: materialy mizhnarodnoi naukovo-praktychnoi konferentsii «Dezvoltarea sistemelor sociale și economice întrun mediu competitiv la nivel global» - Proceedings of the materials of the international scientific-practical conference «Dezvoltarea sistemelor sociale și economice întrun mediu competitiv la nivel global» (Chisinau, February 29, 2016) (pp. 167-171). Chisinau. (in Ukrainian) 
10. Shykina O.V., Honcharenko Ya.Ye., Kozlovskyi R.S. (2019) Tendentsii rozvytku yevropeiskoho rynku hotelnykh posluh [Trends in the development of the European hotel services market]. Naukovyi visnyk Odeskoho natsionalnoho ekonomichnoho universytetu. Nauky: ekonomika, politolohiia, istoriia, no. 5(268), pp. 216-233. Retrieved from: http://n-visnik.oneu.edu.ua/collections/2019/268/pdf/216-233.pdf (in Ukrainian)

11. Shykina O.V., Honcharenko Ya.Ye., Remihailo I.Yu. (2020) Shliakhy rozvytku dilovoho turyzmu u period pandemii [Ways to develop business tourism during the pandemic]. Infrastruktura rynku, no. 50, pp. 213-219. DOI: https://doi.org/10.32843/infrastruct50-35 (in Ukrainian) 